\title{
The Last Temptation of the Philosopher-Rulers
}

\author{
Cathal Woods (Virginia Wesleyan College) ${ }^{1}$
}

In Plato's Republic there are two stages in the philosophers' "return to the cave": an initial failure to rule and a subsequent lament at having to rule. The failure can be seen elsewhere in the work and so needs to be taken seriously. As an explanation for the failure to rule, I propose that, due to their love of the forms, the philosophers forget that they are interdependent members of the city. Finally, I argue that there are no "founders", external to the city, who persuade them, but rather that the philosophers decide for themselves, and that it is the other parts of the soul and the other classes of the city which drive the philosophers to the decision to return.

\section{Introduction}

The section of Plato's Republic known as "the philosophers' return" or "the return to the cave" appears to provide a counter-example to the main thesis of the work, that a person is better off being just rather than unjust. Socrates describes the philosophers as being unwilling to deal with human affairs and so gives the impression that they fare worse when they must do what is just - that is, govern - than they might otherwise. In the scholarly debates on the return to the cave, the issue of the philosophers' aversion to human affairs is often relegated to an afterthought, after the problem of the philosophers' well-being in relation to justice has been addressed. In this article I directly tackle it.

In part 2, I show that there are two distinct stages to the process of the philosophers' aversion to ruling - their initial failure to rule, and, after their decision to return, their lament at having to rule. By the lament I mean the stage at which the philosophers rule but do so begrudgingly. Most scholars, I think, have focused on the lament exclusively, and so I argue

\footnotetext{
1 Thanks are due to Rich Bond, Eric Brown, Amy Coplan, Allan Silverman and Tom Tuozzo, and
} audience members at a meeting of the Society for Ancient Philosophy. 
against accounts (both real and imagined) that the failure is to be explained away (and folded into the lament), rather than explained as an independent stage.

In part 3, on the basis of various pieces of text I suggest that we are driven to the following explanation of the philosophers' failure to rule: due to their love of the forms the philosophers forget that they are interdependent members of the city. They think of the material world only in epistemic terms (they despise the mental lives of those still in the cave) and they fail to remember that they are dependent upon the other members of the city. In the course of defending this position, I show against other accounts that the text does not support the claim that desire of the philosophers to imitate the forms involves to a desire to rule in the city.

The failure is only temporary, as we know. In part 4 I thus discuss how the philosophers come to the realization that dealing with the non-rational world (and specifically in their case, ruling) is the best thing to do. I suggest that there are no other people, external to the city, who persuade them, as the text suggests, but rather that the philosophers decide for themselves, and that it is the other parts of the soul and the other classes of the city, rather than "founders" or other philosophers, which drive the philosophers to the decision to return.

\section{Failure and Lament}

In Republic book 7, the philosophers, Socrates says, who have ascended out of the cave and become accustomed to the outer world and ultimately the sun itself, are unwilling to engage in human affairs (517c9 ${ }^{2}$ ouk ethelousin ta tôn anthrôpôn prattein). They have been blinded by the light, in that they are eager to continue contemplating the forms (and also in the sense that they would struggle to comprehend human affairs in the material world). After some remarks about education, Socrates returns to the philosophers and says that even though they are ecstatic in their new condition, they cannot be allowed to be unwilling and must be persuaded to return (519d5). The persuasion takes the form of a speech about justice which states that it is the philosophers' job to rule the city, both for their own benefit and the benefit of the whole (520b6d6).

${ }^{2}$ Unless otherwise indicated, parenthetical references are to Republic. Translations are from Grube, revised by Reeve (1992), except where noted otherwise. 
Socrates and Glaucon agree that, after the philosophers hear the speech, they will return to the city and rule, for they are just people and will be moved by considerations of justice. Socrates and Glaucon further agree, however, that the philosophers will think of ruling as a necessity or something compulsory (520e1-4 hôs ep anangkaion) and so their return to rule is made with some reservation.

What we can call the philosophers' "failure to rule" (or "failure" for short) appears to be distinct from "the philosophers' lament". That they fail to rule is implied by their unwillingness to deal with human affairs and the fact that some persuasion must be brought to bear on them in order that they will rule. Subsequently, they move to a state involving consideration of both philosophy and ruling, and begrudgingly accept the need for ruling. The just action, in their case, is to return to the cave, but, at least initially, the consideration about justice appears to be missing or lacking in some way, as we shall consider in due course, and the philosophers' desire for philosophy is authoritative.

Since the principal target of scholarship has been the question of whether the philosophers fare better or worse by being just, many scholars have given short shrift to the question of the philosophers' failure, and even their lament. 'Imitation' accounts, for example, hold that philosophers fare well by ruling because ruling provides them with an opportunity to spread the rational order of the forms. But this provides philosophers with a motivation to rule, and so it is difficult to see in what sense they would fail to rule, and even in what sense they might lament ruling. ${ }^{3}$ An explanation of the philosophers' failure (in particular) is also absent

${ }^{3}$ Kraut (1991) gives an explanation of unwillingness which is best construed as addressing the philosopher's lament. He writes that "one can be eager to perform an act [= ruling] because of one of its features and reluctant to do it because of another." (p. 55). By the former feature he means that ruling is what justice requires. By the latter feature he means "to exercise power over others, to give them orders, to correct their errors, and so on".

Mahoney (1992) suggests that the compulsion stems from the fact that "Socrates has created (in speech) conditions under which ruling is what is just for the philosophers to do." (p. 271). Similarly (I think), Brickhouse (1981) construes compulsion as constraint by principle. Cooper (2000) says that the philosophers choose political activities (over "the highest intellectual activities") "as a second best, something forced on them by the circumstances of human life - specifically, by the need that even the best attainable human community has of their rule.".

Vernezze (1992) distinguishes between reluctance to undertake the job of ruling and reluctance in the performance of the job, saying that the philosophers have the former but not the latter reluctance they come to love ruling (p. 157). However, quotes such as 520e2's "go to rule as to something 
from accounts which hold that the philosophers have a debt to their community for their education. Brown's (2000) account, for example, preserves the perceived inferiority of ruling as the basis of the philosophers' lament, but does not explain how the philosophers could forget their debt to the city and fail to rule.

Rather than explain the philosophers' failure to rule, one might explain it away. It's clear that not everything in Republic is to be taken at face value. When Socrates talks of compulsion, for example, we are scarcely to believe that the philosophers are physically moved, or even threatened physically, as Socrates is in the opening pages of the work. The philosophers are persuaded rather than forced; the so-called "compulsion" takes the form of thoughts about justice. Likewise, as I have mentioned already, while in the text these thoughts are presented to the philosophers by Socrates and Glaucon acting as founders, it is doubtful (I'll argue in part 4) that we are to believe that there are these extra-political founders who do the persuading.

In the same spirit one might suggest, perhaps, that Socrates' contention that the philosophers will need to be reminded of their role in the city is rhetoric employed by Socrates to convince Glaucon (and by Plato to convince the readers of the work) of the return because he (and we) do not understand the demands of justice, as the philosophers do. ${ }^{4}$ However, the talk of failure and persuasion is not entirely due to Glaucon's nature, whatever that might be, for Socrates himself prompts Glaucon's protest by describing the philosophers as unwilling and in need of persuasion, beginning at $517 \mathrm{c}$ when he says that the philosophers are unwilling to

compulsory" seem to quite straightforwardly refer to the philosopher's attitude after having decided to undertake the job and not before it. And at 450b the philosopher is described as rotating between ruling and not ruling, and on each occasion that she is called to rule she does so not as "doing something fine but something that has to be done." In other words, Vernezze collapses the lament into the failure. Vernezze might, but does not, try to explain away the subsequent lament. For example, it seems that Glaucon is still (perhaps obtusely, falsely) thinking in the same terms as at the start of the work, when he gives voice to the resentment people feel at being compelled (360c6) to act justly. (They realize that it is better than suffering injustice, but they would (foolishly) rather be able to do injustice.) But as I will shortly describe, the lament is a vital element of the of Republic's political philosophy.

Those who hold that the philosophers' well-being suffers in some way because of ruling might therein have ready material for an explanation for their failure to rule. However, such an explanation would involve both conscious acknowledgement by the philosophers of their duty and a decision (albeit temporary) to put their own interests ahead of the city's (or the forms').

${ }^{4}$ This is the view of Mahoney (1992) p. 271. 
occupy themselves with worldly matters. It is Socrates who is here emphasizing that they initially have a stronger reluctance.

Another form of discounting the failure - perhaps implicit in the fact that scholars have not distinguished the prior stage of the philosophers' unwillingness from their distaste for ruling - might be to claim that Socrates is exaggerating the awe-inspiring effect of contact with the forms (perhaps in order to promote the practice of philosophy), when all he needs for the purposes of the argument is only to describe how the philosophers' contempt for ruling paradoxically makes them good rulers, i.e. the philosophers' lament.

Let us take this opportunity to examine briefly the philosophers' lament. In the larger picture of Republic, it is important that the philosophers be in some sense averse to ruling. One of Socrates' central claims is that a well-governed city is possible only under people who are aware of a way of life that is better than ruling (520e5-521a9, 347c8). The reservation expressed by Glaucon at the end of the return to the cave is an expression of the philosophers' preference for contemplation over ruling and as such, Socrates is willing to endorse it. "That's how it is.", he says. "If you can find a way of life that's better than ruling for the prospective rulers, your wellgoverned city will become a possibility." (520e4-6 ).

The philosophers' evaluation of contemplation remains the same after the decision to rule, and even though the philosophers' failure is overcome and, in some sense of the word at least, they "desire" to rule, they consider ruling to be vastly inferior to contemplation. Wanting to rule (because it's for the good of the polis and themselves) is consistent with the belief that ruling is inferior to philosophy. After they return, they each continue to think, as they perform the work of ruling, "I would much rather be contemplating." — this is the philosophers' lament — but on the other hand, they must continue to think "This is my job." and "What's good for the city is good for me.", and these latter thoughts are governing. Their attitude to ruling does not necessitate an overall desire not to rule; rather, it provides a reservation about ruling. ${ }^{5}$

\footnotetext{
${ }^{5}$ In terms of the three types of good distinguished by Glaucon in book 2 (357 ff.), ruling falls into the third class - it is desirable for its results, though it itself is not valuable.

At the end of book 9, where one might suppose that Socrates is being less indulgent of his interlocutors (and swears "By the dog"), he states that philosophers will be willing to take part in politics in the just city (592a4). This could refer to their overall willingness to rule, or could be taken as
} 
To return to the issue at hand, the suggestion is that because the philosophers' lament is enough to serve as their qualification for ruling, and this is all that is important in the grand scheme of the work, the failure can be ignored as an unnecessarily strong expression of the lament.

In order both to bring out what is distinct and important about the failure and to reinforce the failure as a distinct stage, let us examine the similarities and difference between the return to the cave passage and other similar passages.

Consider first a passage in book 1 . Socrates says there of the best people that "if they're to be willing to rule, some compulsion or punishment must be brought to bear on them" (347c1), where the punishment in question is being ruled by an inferior. They regard ruling, he goes on, as "something necessary". This passage mirrors the return to the cave of book 7 in that it involves compulsion and "ruling as a necessity" (and the use of ethelein at 347a6, b1, b5 and c2). However, when Socrates asserts that the best people will rule only to avoid rule by someone worse than themselves, he could be understood as referring to any city. Socrates has not yet (in book 1) described the education of the philosophers, including both the necessity of support from the community which allows the philosophers to concentrate on the rational element of their souls (and so the need for justice), and the awe-inspiring affect of consorting with the forms. Indeed, there has as yet been no mention of philosophers - the rulers are referred to vaguely as "the best people" (347a8) and "the good people" (347d1) rather than as "philosophers".

Socrates thus does not quite say in book 1 that the philosophers fail to rule while they are in the circumstances which make ruling the right thing to do and which make the philosophers' failure startling. In book 7, they will not rule even though the circumstances are optimal; in book 1 they will not rule, but, for all we know, they will not rule in ordinary societies. The two are the same in that there is something (even if unexpressed) which is desired more than ruling, but there is no explicit mention in book 1 of failing to rule when they should. It is possible that the best people of book 1 are only wary of ruling, because they view ruling as a necessity, rather than failing out-right to rule.

contradicting the failure or the lament, or both. For consistency's sake, I interpret it as their willingness to rule even though they regard ruling as a necessity. 
The book 1 passage, then, is not a perfectly clear instance of the philosophers' failure to rule. There are additional passages, however, which do appear to describe the philosophers (as such, and in the best city) as failing to rule, as opposed to (merely) expressing their distaste for ruling. These occur in book 6, circa 500d4 in the argument against the majority's opinion of philosophers, and at 540a8 (anangkasteon) when the return to the cave is reprised at the end of the discussion of the philosophers' education.

In the first of these passages, Socrates is arguing that the majority can be brought to accept the rule of the philosophers by giving them (the majority) the proper definition and explanation of "the philosophic nature and way of life" (499e3). The philosophers have seen the forms and seek to imitate them in their own souls, but not in anyone else's soul or in the city at large. ${ }^{6}$ The result of the philosophers' consorting with the forms is that although they will try to make themselves as much like the ordered forms they contemplate (500c and 500d), they must be compelled to imitate this order in other people's characters (500d4). The purpose of compulsion in this passage is to change this selfishness, just as in the return to the cave.

In the later context (circa 540), Socrates notes that philosophers must engage in politics at the end of their dialectical training. ${ }^{7}$ This passage (540) does not contain an initial mention of ordering only themselves, but the similarity (to 500) in the description of what the philosophers must do is decisive. Compare the wording of "some necessity arises for him to practice putting what he sees there into the dispositions of men, both in private and in public" at 500d4-5 (Bloom trans.) with "they must be compelled, each in his turn, to use it [the form of goodness] as a pattern for ordering city, private men, and themselves" at 540a9-b1 (Bloom trans.).

These two passages, then, in addition to the return to the cave itself, assert the philosophers' failure. All three passages follow the same pattern, of failure to rule followed by

${ }^{6}$ As I shall argue when I return to this passage again in section 3, below.

${ }^{7}$ The philosopher must also be compelled to return during his or her training (539e2). Socrates does not say that the final return, after seeing the form of goodness, is more difficult than the first, and so this passage seems to agree with the passage circa 500 in making knowledge of the forms in general, rather than the form of goodness in particular, sufficient for distraction.

It is also worth pointing out at this point that the philosophers return to contemplation at some point(s) after the completion of their education. The repeated cycle of dealing with forms and politics, both during and after training, suggests that the philosopher must be "compelled" to return to the cave on multiple occasions and so that the philosopher must re-fight the battle with him- or her-self each time. 
compulsion, with subsequent lament. In light of these, it is difficult to accept that the failure should be discarded as an exaggeration and conflated with the lament. There might be other ways in which to neutralize the failure, but in the text, Socrates appears to uphold a distinction between the desire of the philosophers to emulate the forms in their own case, and the (begrudging) desire to fashion the community after the forms. These passages maintain that the philosophers fail to rule even though they are in the circumstances which, if the philosophers were cognizant of them, would bring about the philosophers' governance. The lament, by contrast, portrays the philosophers as ruling, though wishing for contemplation. Socrates seems to be insisting that there is a real possibility that the philosophers might not rule. ${ }^{8}$

\section{Failing to Rule}

In taking seriously the philosophers' initial failure to rule, we reach a fundamental paradox of the philosophers' return, namely that the very people who have reached the pinnacle of Republic's education, who understand the forms and the form of goodness, fail to do what is good. The just action, in their case, is to return to the cave, and when they become aware of this they do so. But initially at least, they are not aware that this is the right thing to do. How can these most knowledgeable of people lack the belief that the best thing to do is to rule? ${ }^{9}$

The failure of the philosophers to return is remarkable because reaching this stage requires extensive training in both character and intellect. Those who have reached the final stages of the educational process are those who have been able to maintain the beliefs that they must do what is beneficial for the city and that what's good for the city is good for them (412d4e6 and ff., 502e2-503a2). It seems that after successfully maintaining throughout the course of all of this training the belief that their own interests and the interests of the city coincide, the philosophers' upbringing is undone by their attraction to the forms. Hence the title of this article

\footnotetext{
${ }^{8}$ A direct answer to the deflationary suggestion that the failure is an unnecessarily strong form of the lament depends on the contents of section 3. Socrates cannot have the philosophers (initially) acknowledge both philosophy and ruling simultaneously because the soul of the philosopher has to be 'hammered away at' from birth so that the rational soul might be allowed to flourish, free from the mortal elements of soul. The (almost) other-worldly existence of the philosophers matches the other-worldly existence of the forms.
}

${ }^{9}$ See Aronson (1972) p. 394. 
— the last temptation of the philosopher-rulers. The task of the current section is to show that the best way to understand the philosophers' failure is to think that the beliefs they have so far been able to maintain are forgotten by the philosophers, due to the immense attraction of the forms and the separation of oneself from one's body in contemplating them. This temptation is so powerful that, for a time at least, the philosophers are blinded to their role in the polis by the dazzling brightness of the sun.

One cannot help but be impressed by the emphasis in Republic on intellectual education and especially by its culmination in knowledge of forms, as portrayed in the striking images of Sun, Line and Cave. Having achieved these heights, the philosophers, as Socrates describes them, are infatuated with the forms. He portrays the philosophers as being in the grip of something psychologically compelling, their souls always "pressing upward" (517c6). In its most ecstatic expression, understanding the forms is so wondrous to the philosophers that it is said that they think they have come, while still alive, to the Isles of the Blessed (519c6; see also 540 ${ }^{10}$ ).

Attraction towards the forms simultaneously distracts the philosophers from mundane concerns. When they look "downward", back into the cave, they evaluate the situation there in epistemic terms, rather than the evaluating the political situation. They compare their current enlightened state with the limited reality of ordinary people ${ }^{11}$ (517 ff). Cave-dwellers deal only with appearances. They contemplate the shadowy forms on the wall of the cave and take them for realities and compete for pleasures and honors (520b9, 521a6). The philosophers consider their enlightened state so worthwhile that they would prefer to work as serfs to others, rather than revert to the opinions and life of the cave-dwellers (516d4). They have no interest in competing with the other members of the community over the shadows in the cave, which would lead to filling their souls with "envy and hatred" (500b10).

The philosophers do not consider human life to be anything important (486a8). This extends not only to dealings with other people who are ignorant of the forms, but to the other

\footnotetext{
${ }^{10}$ Each of the "additional" passages (at 500 and 540) makes mention of the heightened epistemic state of the philosophers. This is true even of the passage at 500, even though it precedes the allegories of Sun, Line and Cave and does not mention the form of goodness.

${ }^{11}$ Since 518c4 tells us that everyone has a soul capable of education, it must be that they look at adult souls, which have been malformed by their association with the other parts of the body (cf. 519ab).
} 
parts of the philosophers' own souls. At his most emphatic, Socrates says that because the philosophers "love all such learning and are not willing to give up any part of it, whether large or small, more valuable or less so" (485b3), they abandon (ekleipoien) the pleasures of the body (485d10). ${ }^{12}$ Indeed, by thinking that they have died and gone to the afterlife, the philosophers have in some sense abandoned their bodies. As in the rest of Hades, the Isles of the Blessed are a place where the body becomes insubstantial and has no nutritive or protective needs, ${ }^{13}$ and there is thus no need to spend any time thinking about how to satisfy these desires. In such a place, one can philosophize all day long. ${ }^{14}$

Even though the work is famous for its tri-partite psychology, there's some evidence in Republic itself that reason alone constitutes true soul, at least when it is separate from the bodily elements. Socrates says, "[N]or must we think that the soul in its truest nature is full of multicolored variety ... we must not study it as it is while it is maimed by its association with the body" (611a, b). Instead of examining the soul when it is beset by the many evils of human life, Socrates states that we must look "[t]o its love of wisdom, and recognize what it lays hold of and with what sort of things it longs to keep company on the grounds that it is akin to the divine and immortal and what is always" (611e1-3 Bloom trans.). ${ }^{15}$ Socrates is non-committal about whether the true soul has parts or not, ${ }^{16}$ (he goes on to say that only in this state will we be able to see "whether it has many parts or just one and whether or in what way it is put together"

\footnotetext{
${ }^{12}$ Neglect of human things is also of a piece with the philosophers' being blinded by the darkness upon their return to the cave. If they should be compelled to compete with the people who live there they would look ridiculous (517a, d) because they are unable to make sense of the shadows. The knowledge that the philosophers have as a result of contemplating the forms does not immediately enable them to comprehend the subterranean shadows and neither do they want to practice on the material world. Their eyes must adjust in order to put the knowledge they have acquired "above" into practice. (And indeed, despite their initial difficulties, and the fact that they would be killed if they tried to free the cave-dwellers from their mental slavery (517a), they are the people best able to bring order to the political world (500d).)

${ }^{13}$ Or, the man $(588 \mathrm{~d} 3)$ in side the man $(588 \mathrm{~d} 8)$ is set free.

${ }^{14}$ At the end of Socrates' Defense, Socrates hopes to spend the rest of his life talking with heroes and the wise (40e-41b).

${ }^{15}$ In their interpretations of Republic as a whole, Strauss (1964) and Bloom (1968) emphasize the thought that Plato "disregards the realities of human nature." (This phrase is from Hall (1977).)

${ }^{16}$ This was pointed out to me by Eric Brown in correspondence.
} 
(612a)) but these quotations make clear both that the bodily elements of the human soul are considered detrimental and that the soul's pure state is to be free of them and "longs with its whole being" to associate with the forms. ${ }^{17}$

The education of philosophers requires that their souls have been hammered at (612a, 519ab) all their lives in order to free the divine nature from the degradations of the mortal soul, but doing so has also given the philosophers the lightness to be pulled clear of the sea (612a1) into, as one modern poet puts it, the "wide, light fields of ontology". ${ }^{18}$ The philosophers, who have been brought up in part so that they can attend to the well-being of others, have at the same time been taught to become so enamored with the forms that they care only for intellectual activity, even to the exclusion of their bodily natures.

The nature of the "cure" also indicates that the precise nature of the failure is that the philosophers' former beliefs - that the role of a philosopher is to rule and that "what's good for the city is good for me" - have been forgotten, (or, which will be equivalent for my purposes, they somehow retain the beliefs but think that they no longer apply to them. $)^{19}$ Socrates responds to the philosophers' failure to rule by saying that they must be reminded of their mutual interdependence with the other classes. Socrates says that he will remind the philosophers that they are "kings in our city and leaders of the swarm, as it were, both for [them]selves and for the rest of the city" (520b5-7). The remedy for the philosophers' failure to rule is to have them recognize the belief that they benefit from playing their part in the city. (On the psychic level, the equivalent event would be for the philosophers to remember that they are in fact tri-partite beings.) Without recovering this perspective, the philosophers commit an injustice, the injustice that reason, greedy for its distinctive (intellectual) pleasure, born of desire and distaste, commits against the fellow citizens and against the other parts of the soul.

17 Silverman, in (Shields (ed.) 1993), writes that "on its own and in its own right, a soul is simply something that reasons and reasons about Forms" (p. 132).

${ }^{18}$ Goldbarth (1991) p. 26

19 The important point is that the beliefs lack any motivational force. It cannot be that they have diminished force (but is overridden by the attraction to the forms) as this would indicate an unresolved tension within the souls of the philosophers. 
Journal of Ancient Philosophy Vol. III 2009 Issue 1

The philosophers appear to be ignorant of the fact that they (the philosophers) are dependent upon those others for their livelihood. That is, Socrates appears to be saying that the philosophers, under the influence of the forms, simply do not think about the standing mutual obligations between philosophers and citizens, or between reason and the other parts of the soul, and so see no need to rule. Rather, (as mentioned already) if they think about fellowship with other people at all, they think of it in terms of communing with other the just souls, i.e. with philosophers. $^{20}$

Now, one might argue that the philosophers' desire for contemplation is consistent with a desire to rule, and indeed, some ${ }^{21}$ have argued that, contrary to the "pulling away" from the material world we have just seen, the philosophers wish to govern, due precisely to their love of the forms.

${ }^{20}$ A community in all cases is a community of souls, but Republic suggests different kinds of communities. There is (possibly) a community of pure souls, that is, of entities comprised entirely of reason (alluded to by the Isles of the Blessed); a community of philosophers, that is, of reasons embodied in just humans; a kallipolis, that is, of philosophers living with people with thumotic and appetitive souls, and further degradations of community, as described in books 8 and 9. Philosophers, if they aim at community at all, might aim at the first or second of these. In these first two, the souls are equal but separate; in the latter, they are hierarchically distinct, requiring a relationship of dominance and subordination. (The same - that there are hierarchical and non-hierarchical versions — can also be said about justice. See the fn. after next.) The first two, which are not explicitly mentioned in the text, are analogous to an extent with the city of pigs. Socrates expresses approval for the so-called 'city of pigs' in book 2. Having constructed the first city, Socrates pauses to ask Adeimantus if he can see justice anywhere in this city, and Adeimantus replies that it is somewhere in the need the people have of one another (372a). Glaucon then protests the lack of delicacies, to which Socrates responds by goading him with further description of his (Socrates') "healthy" and "true" city (372e) but, then, paradoxically, goes along with Glaucon leading to the addition of the warriors and the guardians. More consistently with his apparent position, however, is that over the course of kallipolis' construction Socrates systematically deprives these new classes of all the benefits to the appetite that Glaucon had insisted upon, as befits their distinctive natures. This first city, the city of pigs, seems 'healthy' and 'true' because there is no class differentiation, due to fact that the artisans and farmers do not have immoderate appetites. Justice in this city, as Adeimantus says, has something to do with the need that the citizens have of one another. Although he expresses himself doubtfully, this answer is worth taking seriously, first, because Socrates' immediate response is 'you might be right', and, more importantly, because Adeimantus is at heart repeating the principle of specialization with which Socrates begins the construction of the cities (at 369bc), and which eventually (at 433a ff) is called justice. (For some discussion see Deslauriers (2001), along with Barney (2001), McKeen (2004) and Silverman (2007). Deslauriers argues that the device of founding cities in speech is used to expose the nature of some thing. I concur, and take the city of pigs to introduce the principle of specialization.)

${ }^{21}$ I have in mind here the "imitation" accounts of Kraut (1991) and Cooper (2000). 
The idea is that contemplation of the forms itself brings about an expansion of the philosophers' interests beyond and against contemplation for the philosophers. The forms are characterized as being "set in a regular arrangement and ... always in the same condition [and ...] neither do injustice to one another nor suffer it at one another's hands, but remain all in order according to reason" (500c2-6 Bloom trans.). ${ }^{22}$ The philosophers are described as wishing to imitate the forms and no one, Socrates says, can "consort with the things he admires without imitating them" (500c7-8). Socrates says that the philosophers try to imitate the forms by leading as good a life "as is possible for a human being" at $500 \mathrm{~d} 1{ }^{23}$ This imitation does not amount to anything else beyond trying to lead the rational life described just above. Socrates states that each philosopher "tries to become as like them [the forms] as he can" (500c3 hoti malista), and, as we have seen already concerning this passage, he further states that compulsion is necessary in order to expand its range. Their emulation of the forms does not involve any other individual or

${ }^{22}$ The forms are just towards one another, and as such presumably partake of the form of justice., though there is no explicit mention of this. (They would also partake of other moral and perhaps aesthetic forms, such as moderation and beauty (as well as Statesman's greatest forms.) These are applicable also when trying to make a material entity as good as possible. It is towards such forms that the philosophers look when ordering the city. At 501b Socrates says that the philosophers look "towards the natures of justice, beauty, moderation and the like" and at 520c towards "the fine, just and good things". There does not appear to be a form of city. At 592b2 Socrates say that there might be a model (paradeigma) of the best city in heaven. But he immediately follows this already tentative claim with the assertion that it doesn't matter whether the best city exists anywhere (either on earth or in heaven) - the philosopher will organize himself (and his city, if possible) in whatever way will produce the best condition of his soul. In adding these remarks, Socrates can be taken as suggesting that the vision of the just city and just soul is one that the philosophers work out for themselves and contain within their own souls. (See Burnyeat (1999 p.299) for further discussion of this passage.) Although justice everywhere is each part doing and having its own, it's not clear whether justice as instantiated by the forms is akin to the justice of the city of pigs and in any community of philosophers or of pure souls - where the whole is constructed of equal parts - or to that in the human soul or the kallipolis (or other human communities) — where its parts are qualitatively different and the whole is structured hierarchically. Some forms, perhaps, apply to other forms, while others do not, and thus might be counted as being of a different order, and the form of goodness somehow stands over the whole. On the other hand, all of them, including justice, beauty and so on, are the same insofar as they are forms. The presence of hierarchy in the relationship amongst the forms might (though it's not clear how, exactly) suggest to the philosophers that, in imitating the forms, they must have one part of soul dominate the others, contrary to what I have assumed above.

${ }^{23}$ See Sedley (1999) for discussion of homoiôsis theôi particularly as it appears in Theaetetus and Timaeus. 


\section{Journal of Ancient Philosophy Vol. III 2009 Issue 1}

the community at large (500d5). ${ }^{24}$ It's not even clear, I've suggested above, that it extends to the other parts of the philosopher's own non-rational soul. When the philosopher's attention is extended to others the language of necessity or compulsion in introduced (500d3) and the philosopher is described as inculcating in others "moderation, justice and the whole of popular virtue (dêmotikês arêtês)". That moderation and justice are described as "popular" virtue here is notable. The philosophers too are attempting to become just, since they are imitating forms which neither do nor suffer injustice. Popular or demotic justice would then be something different. "Demotic virtue" might plausibly be understood to refer here to the virtues involving of the lower parts of the soul in people without their own guiding principle of reason ${ }^{25}$ while what we might call "philosophic virtue" does not.

The reason for the philosophers' aversion to ruling is not their fear of death at the hands of the citizens, as would happen in the cities of the spontaneous philosophers mentioned at 520. There, Socrates reminds Glaucon that their job is "not to grant them [the philosophers] what is now granted" (519d2-3 Author's trans.). The reference to 'what is now granted' is explained a little later (520b1 ff): Some people manage to become philosophers in other cities, and these cities, which do not support the study of philosophy, do not require its practitioners to take part in public life. Indeed, the philosophically-minded citizens of such cities shun political activity, in part because they know it will get them killed (496d1). Hence, they fail to participate. Concerning the philosophers who imitate the forms, Socrates seems to be insisting that these people fail to rule, like the spontaneous philosophers do in other cities, even though the lives of these philosophers are not threatened by living in unruly communities. Since, in the best city, the philosophers can rule over a willing populace, there must be another reason for their unwillingness. The reason is as we have described above: the philosophers' attraction to the forms and their negative attitude towards the non-rational.

\footnotetext{
${ }^{24}$ Brown (2004) p. 279-280 also makes this point.

${ }^{25}$ Demotic virtue is perhaps a private version of civic (politikên) virtue (see 'civic courage' at 430d3), and refers to those who lack the ability to organize themselves. Penner (1999) supplies further references, to Phaedo 68c-69d, 82a-b and Statesman 305e-310a. Penner, putting civic and demotic virtues together, describes them as those virtues "which do not require knowledge or wisdom" (p. 84).
} 
To summarize: Our question was 'What is the cause of the philosophers' failure to rule?' Our answer is that their pursuit of the forms means that they conceive of themselves as purely rational beings and pay no attention to the non-rational facets of their lives, both private and public. The philosophers' infatuation with contemplation causes them to abandon the material world as the repulsive home of the benighted. By perceiving the material only in this way, the philosophers forget that they are members of the more mundane community which makes philosophy possible for them as tri-partite beings and they fail to abide by their former conviction that what's good for the city is good for them, and that their place in the community is to rule. ${ }^{26}$ Knowledge of the forms changes the ground-rules for what counts as a good life. The best human life for ordinary humans is centered around political activity; the best life for philosophers is solely focused on intellectual endeavors involving unchanging forms.

\section{The Decision To Rule}

We know that the philosophers' failure to rule is only temporary. How do the philosophers come to recognize that they should rule? Above, I have described the philosophers as losing sight of the beliefs that their job is to rule and that what's good for the city is good for them. Thus, I think that they decide to return to rule when these beliefs are re-instated. This, very general, position is in harmony with the text, which describes the philosophers' decision to return as resulting from a reminder about the philosophers' position within the city. However, in the text this 'compulsion' or 'persuasion' is executed by Socrates and Glaucon and with this my more specific position is not in agreement. ${ }^{27}$

\footnotetext{
${ }^{26}$ In effect, I have argued in defense of both parts of the "contemplative ideal". The contemplative ideal is a picture of the philosophers as striving toward a life "devoted to learning and the contemplation of the truth" (Nussbaum (1986) p. 138.) along with an attendant desire to avoid practical affairs. However, I have tried to make clear that the philosophers do not have an explicit desire not to rule, but rather have forgotten and so neglect the material world. "Practical affairs", that is, does not mean ruling, but only (less specifically) dealing with the material world. The contemplative ideal has come under attack precisely because of the problem of the philosophers' return - the philosophers (it is argued) benefit from being just and ruling in addition to, or rather than, from contemplating, as though these two were in conflict. If these can be reconciled, (as I argue they can, in Woods (unpublished)), the theoretical impulse running contrary to the contemplative ideal loses steam.
}

${ }^{27}$ Glaucon and Adeimantus, each being Socrates' interlocutor at different times, are each founders. 
Together in their role as "founders" (519c) Socrates and Glaucon remind the philosophers that they (the philosophers) are members of the city and that by ruling everyone, the philosophers included, will benefit. Socrates and Glaucon, however, are not explicitly described as members of the kallipolis, and so the question arises as to whether they can possibly do the reminding. If not, who does? Some founder or founders within the kallipolis? ${ }^{28}$

Various pieces of text might support the view that the founders are internal to the city: At 497c Socrates says that there must be "some people in the city who have a theory of the constitution, the same one that guided you [here = Adeimantus], the lawgiver, when you made the laws." More importantly, at 501a Socrates says that when the philosophers take charge of the city, they begin by sketching an outline of the constitution and at 502b6 that "a ruler establishes the laws and they ways of life we've described". ${ }^{29}$ Thus, it seems that the role of the philosopher is not restricted merely to the continuation of the constitution which some other founder has put in place (which the passage at 497 might suggest), but can also be the originator. In this way, there is no need to think that Socrates, Glaucon and Adeimatus in particular are the founders of the polis and neither that the founder is external to the polis. Instead, one can assume that there are people within the kallipolis itself who understand the foundations of the state.

These people — the already-existing philosopher-rulers — could perform the role of Socrates and Glaucon in compelling people to return to rule. But the problem arises of how these philosophers came to choose ruling. A regress ensues if we explain the turning of a philosopher or philosophers towards ruling by the existence of previous philosopher-rulers. ${ }^{30}$

\footnotetext{
${ }^{28}$ Brown (2000) appears to take the talk of founders entirely at face value.

${ }^{29}$ The philosopher-rulers are responsible for maintaining the constitution, which requires knowledge of it. See 412a: "we always need this sort of person in our city, Glaucon, if indeed its constitution is to be preserved." and 505ab: "won't our constitution be perfectly ordered, if a guardian who knows these things [i.e. how the just and fine things are good] is in charge of it?"

${ }^{30}$ The issue of the philosopher choosing to rule (i.e. deciding that ruling, in a good city, would be good for him to do) is different from the question of how the (first) philosopher actually gains the position of ruler in a city. And both are different from the question of what a philosopher-ruler would do in practical terms in order to model the city on the forms. This article considers the first of these issues only. On the second, see 473 . On the third, see 501 and the end of book 7.
} 
I propose instead that we should not look for a chain of influence but rather expect that each philosopher must decide, for him- or herself, that he or she wants to return. ${ }^{31}$ The 'return to the cave' is the moment when the truth of the proposition "what's good for the city is good for me" must be certified by the philosophers themselves, rather than remaining a piece of dogma. ${ }^{32}$ To use the language of the course of education in Republic itself, this is the moment when the hypothesis must become itself a first principle (510b-511e).

But if there is no external founder and each philosopher must decide the matter for himor herself, and yet the philosopher is infatuated with the forms, we seem to be at a loss. We are back at the original problem of this section: the philosophers, in the grip of their infatuation with the forms, fail to rule, and this was precisely the reason that the founders were needed in the first place. If there is no deus ex machina to drag them back, we might well draw the conclusion that the return to the cave (and like sections) shows that it is here that Republic falls apart. ${ }^{33}$

Thus far we have been working under the assumption that some great intelligence is needed to put the philosophers back on track and willing to direct the state. But there is, perhaps, no need to suppose that some external agent, or a kallipolis with an established training program, is needed. The speech which Socrates delivers to the philosophers asserts to them that they are a part of the city, and that their participation in the city is beneficial to all concerned, not just the rest of the city but themselves too. So, I propose that rather than an intelligence equal to or greater than the philosophers' what provides the philosophers with the impetus for examination of the issue is the needs that all the parts of the city have on one another, and in particular, that

${ }^{31}$ Cooper (2000) states: "Socrates speaks of himself together with Glaucon and Adeimantus, the notional "founders" of the city, as the ones who will do the forcing. But, of course, he has to mean instead (as every reader is expected to see) that the complete philosophers (they, after all, are the sole rulers in the city) will maintain it as a practice for themselves." (p. 20). Silverman (2007, p. 49) writes: "I am going to assume that there is no difference between the founders, the law, and philosophy itself (i.e. the fully reflective philosopher)."

${ }^{32}$ Beatty 1976b pp. 135-6 expresses surprise at the idea that the philosophers are simply indoctrinated into the belief that justice is in their advantage. As he writes elsewhere (1976a), "Philosophic questions cannot be finally resolved either by faith or social engineering." (p. 570). Brown (2004) thinks that the philosophers will keep to what is just because they have been well brought-up (p. $283 \mathrm{ff}$.) but this position does not acknowledge the failure and again, there might be a question about how the education system gets up and running in the first place.

${ }^{33}$ See Bloom (1968) p. 407. 


\section{Journal of Ancient Philosophy Vol. III 2009 Issue 1}

the philosophers have of the other citizens. Or put simply, justice. The philosophers are just individuals, and know that justice is each part doing and having its own. The problem, as I diagnosed it above, is that they lack a complete list of parts. Because they pay them no attention, the philosophers fail to realize that the demands of their appetites and their thumotic elements are best satisfied by ruling. ${ }^{34}$

These other parts assert themselves naturally. Concerning parts of the soul, as much as a philosopher might try to deny her human nature, she cannot escape it, and so is compelled to consider the best care of her human soul. As stated already, the philosopher's desire to be merely a rational soul, (perhaps in a community of rational souls), is an injustice against the other parts of her human soul. Concerning the parts of the city (if we suppose the philosopher in question is not the first philosopher), the other classes (and indeed the other philosophers) will not allow the philosopher to ride for free. If a population is willing to support a philosopher, it is only because the philosopher is of some use to the citizens, as a ruler.

The struggle between the pure soul and the material soul, or between philosopher and citizens, is sufficient to ground the philosophers and force them to turn their attention to the material world as such. It is by being compelled to take this human perspective or this political perspective that the philosophers recognize their social position and become concerned with their position in relationship to others of different types. Through the recognition of their human and political nature and their political circumstances, they come to appreciate the demands of justice: philosophers are not self-sufficient; they are citizens of a non-homogenous citizenry who make it possible for them to concentrate so much on rational activity. And so they must consider how the other parts should live. That is, they rule and so bring about and maintain that state in which all classes do and have their own and benefit from that justice.

The allure of the forms does not diminish, but having been set on the path back into the cave, the philosophers convince themselves that, lamentably, ruling is necessary.

\section{Conclusion}

${ }^{34}$ I have defended the claim that the philosophers fare best, in terms of contemplation, by ruling in Woods (unpublished). 


\section{Journal of Ancient Philosophy Vol. III 2009 Issue 1}

One might ask, 'What is the motivation of the philosophers as they return to rule - is it justice, or self-interest, (or the desire to instantiate the forms)?' The question need not have a single answer which excludes the others, for, as I have stated it above, to understand justice is to understand how to balance one's own well-being with the well-being of others in mutual interdependence. Self-interest coincides with justice as is in keeping with the main thesis of Republic — that one fares better by being just than unjust.

I have argued that Socrates portrays the philosophers' attraction and likeness to the forms as being sufficient to cause them to disengage with the material world. Contemplating the forms is like getting lost in a good book - for a moment, one steps into another world. These most virtuous of people forget for a moment the beliefs instilled by their training. They lack the "just orders" (520e1) that compel them to rule. The difference between the two stages - the philosophers' failure and the philosophers' lament - is the absence, and then the presence, of a countervailing claim on the philosophers' time and effort. The human and thus political nature of the philosophers themselves brings the philosophers back to earth and forces them to and recognize their dependence on the rest of the city and overcomes the last temptation of the philosopher-rulers.

\section{Bibliography}

Aronson, Simon. 1972. "The Happy Philosopher — A Counterexample to Plato's Proof"' Journal of the History of Philosophy, 10, pp. 383-398.

Barney, Rachel 2001. "Platonism, Moral Nostalgia, and the 'City of Pigs", Proceedings of the Boston Area Colloquium in Ancient Philosophy XVII, John Cleary and Gary Gurtler eds., Brill, Boston, 2002, pp. 207-227.

Beatty, Joseph 1976a. "Plato's Happy Philosopher and Politics", The Review of Politics, 38.4, pp. 545-575.

Beatty, Joseph 1976b. "Why Should Plato's Philosopher by Moral, and Hence, Rule?", The Personalist, 57, pp. 132-144.

Bloom, Allan 1968. The Republic of Plato, Basic Books, New York. 


\section{Journal of Ancient Philosophy Vol. III 2009 Issue 1}

Brickhouse, Thomas C. 1981. "The Parardox of the Philosophers' Rule", in Nicholas Smith (ed.) Plato: Critical Assessments vol. III, Routledge, New York, 1998, pp. 141-152. Reprinted from Apeiron 15, pp. 1-9.

Brown, Eric 2000. "Justice and Compulsion for Plato's Philosopher-Rulers", Ancient Philosophy, Vol. XX.1 (Spring).

Brown, Eric 2004. "Minding the Gap in Plato's Republic", Philosophical Studies, 117.1-2, pp. 275-302.

Burnyeat, Miles 1999. "Utopia and Fantasy: The Practicability of Plato's Ideally Just City", in Fine (ed.) 1999.

Cooper, John M. 2000. "Two Theories of Justice", PAPA, 74.2 (Nov.) pp. 5-27.

Deslauriers, Marguerite 2002. "Commentary on Barney", Proceedings of the Boston Area Colloquium in Ancient Philosophy XVII, John Cleary and Gary Gurtler eds., Brill, Boston, pp. 228-235.

Fine, Gail (ed.) 1999. Plato 2, Oxford University Press, Oxford.

Goldbarth, Albert 1991. Heaven and Earth: A Cosmology, University of Georgia Press, Athens.

Grube, G. M. A. 1992. Plato, The Republic, revised by C. D. C. Reeve. Hackett, Indianapolis.

Hall, Dale 1977. "The Republic and the Limits of Politics", Political Theory, 5, pp. 293-313, with a reply by Bloom, pp. 314-330.

Kraut, Richard 1991. "'return to the cave': Republic 519-521", BACAP 7, pp. 43-61.

Mahoney, Timothy 1992. "Do Plato's philosopher-rulers sacrifice self-interest to justice?", Phronesis, Vol. XXXVII/3.

McKeen, Catherine 2004. "Swillsburg City Limits (The 'City of Pigs': Republic 369C-372D)", Polis, 21, 2004, pp. 70-92.

Nussbaum, M. 1986. The Fragility of Goodness, Cambridge University Press, Cambridge.

Penner, Terry 1999. "The Unity of Virtue", in Fine (ed.) 1999.

Sedley, David 1999. "The Ideal of Godlikeness", in Fine (ed.) 1999.

Shields, Christopher 2003. Blackwell Guide to Ancient Philosophy, Blackwell, Oxford.

Silverman, Allan 2007. "Ascent and Descent: The Philosopher's Lament", Social Philosophy and Policy, pp. 40-69.

Strauss, Leo 1964. The City and Man, U. of Chicago Press, Chicago.

Vernezze, Peter 1992. "The Philosopher's Interest", in Nicholas Smith (ed.) Plato: Critical Assessments vol. III, Routledge, New York, 1998, pp. 141-152. Reprinted from Ancient Philosophy 12.

Woods, Cathal (unpublished). "As Happy As Can Be: How Republic's Philosophers Fare Best By Ruling". 